\title{
AN UNUSUAL COMPLICATION AFTER STELLATE GANGLION BLOCK BY THE PARATRACHEAL APPROACH: A CASE REPORT
}

\author{
JAMES B. FORREST
}

THE PARATRACHEAL APPROACH for blockade of the stellate ganglion has been recommended as the safest route ${ }^{1}$ because of its technical simplicity and lack of complications ${ }^{2}$ when low doses of local anaesthetic solutions are used. Subarachnoid block associated with infiltration of the stellate ganglion has been cited as a rare complication., ${ }^{1,3-9}$ The evidence from the literature would suggest that the commonest cause of subarachnoid block is accidental dural puncture either by directly entering the spinal canal, particularly when the lateral or anterolateral route is employed ${ }^{1}$ or through an abnormal dural extension through the intervertebral foramena such as cervical meningocele. ${ }^{10}$

The case of inadvertent subarachnoid block described by Magora ${ }^{6}$ and discussed by Moore ${ }^{7}$ where the paratracheal approach was used would seem to have resulted from penetration of the subarachnoid space caused by sudden movement by the patient during injection.

The use of repeated injections of the stellate ganglion in the management of intractable pain of the sympathetic dystrophic types has gained popularity during the last three decades because of the high rate of long-term remission. Serial blocks are thought to disorganize the reflex activity which is triggered in the internunceal neuronal pool of the spinal cord as well as in the sympathetics themselves. ${ }^{2}$

The following case is presented to emphasize a possible hazard of repeat stellate ganglion block by the paratracheal route.

\section{Case Report}

A 54-year-old woman was referred to the Pain Clinic for the management of left upper limb Raynaud's phenomena complicating long-standing diabetes mellitus. A diagnosis of bilateral carpal tunnel syndrome had been made about 18 months previously and was associated with marked median nerve sensory loss with paraesthesia particularly on the left side. Left carpal tunnel decompression was performed under I.V. regional block with 1.5 per cent lidocaine, but did little to relieve her symptoms. Indeed, during the months after surgery the pain was much worse, being aggravated by cold, emotion and exercise. When she was first seen at the clinic, she had moderately severe loss of motor function of the left hand and virtually continuous pain; the left hand was also cold and pale, indicating moderate ischaemia.

The patient was a fairly heavy smoker (more than 20 cigarettes per day) and

'Department of Anaesthesia, McMaster University, Hamilton, Ontario.

Mailing address: McMaster University Medical Centre, 1200 Main Street West, Hamilton, Ontario, Canada, L8S 4J9

Canad. Anaesth. Soc. J., vol. 23, no. 4, July 1976 
was moderately overweight. Diabetic control was maintained on $40 \mathrm{U}$ Lente Insulin and $50 \mathrm{U}$ Toronto Insulin daily. Fasting blood sugars on this regimen varied between 300 and $500 \mathrm{mg} / 100 \mathrm{ml}$. Additionally she was receiving diazepam $30 \mathrm{mg}$ daily and quinal barbitone (seconal) $600 \mathrm{mg}$ nocte. The lungs were essentially clear, apart from a few scattered rhonchi. The heart was of normal size and on auscultation was normal, but mild ischaemic changes were present on EKG. She was booked for a series of outpatient stellate ganglion blocks, to alleviate her pain and also to improve the circulation to the left hand.

The paratracheal approach was used to block the stellate ganglion on the left side. With the patient lying supine and the head slightly extended, the sternomastoid muscle was retracted laterally and an $8 \mathrm{~cm}$ 22-gauge spinal needle was inserted $5 \mathrm{~cm}$ above the sternoclavicular joint, medial to the pulsating carotid artery. The needle was advanced about $2 \mathrm{~cm}$ onto Chassaignac's tubercle on the transverse process of $\mathrm{C} 6$. The needle was then withdrawn $0.5 \mathrm{~cm}$. Following aspiration, $1 \mathrm{ml}$ of bupivacaine $0.5 \%$ was injected. Successive injections of $1 \mathrm{ml}$ followed by aspiration were made every minute to a total dose of $5 \mathrm{ml}$.

This initial block produced a left Horner's syndrome and completely relieved her symptoms for about eight hours after which there was gradual return of pain over three hours, but normal motor function of the left hand persisted until the next block, done three days later using the same dose and exactly the same technique. This second block resulted in 24 hours of pain relief. However, later on the next day, she complained of a sharp tingling in her fingers and pain in the wrist. A third injection was therefore done some 30 hours after the second. After $1 \mathrm{ml}$ of 0.5 per cent bupivacain had been injected at the same site as previously and by the same technique, and during aspiration check, the patient complained of numbness in the contralateral (right) hand. Within a minute, there was increasing bilateral upper limb anaesthesia and paralysis. The needle was withdrawn and she was given 35 per cent oxygen to breathe by mask, an intravenous infusion of lactated Ringer's solution with $\mathrm{NaHCO}_{3} 25 \mathrm{mEq}$ per $500 \mathrm{ml}$ was instituted and EKG monitoring was begun. A venous blood sample taken at this time showed 291 $\mathrm{mg} / 100 \mathrm{ml}$ of sugar. She was given $5 \mathrm{gm}$ dextrose intravenously, since she was fasting and had taken her usual dose of insulin. Within four minutes of stellate ganglion injection, she complained of difficulty in breathing and spreading numbness of both lower limbs despite a head-down tilt. Accordingly atropine $0.6 \mathrm{mg}$ and succinylcholine $60 \mathrm{mg}$ were given intravenously, the trachea was intubated and she was ventilated with 100 per cent oxygen. The blood pressure before the block was $160 / 90 \mathrm{~mm} \mathrm{Hg}$ and the heart rate $80 / \mathrm{min}$ in sinus rhythm. Five minutes after the block the blood pressure was $95 / 60 \mathrm{~mm} \mathrm{Hg}$ and the heart rate $60 / \mathrm{min}$ in sinus rhythm. The head-down tilt was increased with little change in blood pressure, which remained at this level for about 30 minutes returning to preblock levels over the next 20 minutes.

The patient remained fully conscious throughout and neurological examination done at the height of the spinal block showed complete somatic sensory loss caudal to the C4 segment. Motor loss was patchy, but involved all four limbs, abdominal muscles and intercostals. Diaphragmatic movement was intact. There was an intense Horner's syndrome on the left side and some slight motor weakness of the 
right side of the face but no other evidence of cephalad spread of the block. The patient was extubated after 40 minutes, at which time she had full return of motor function. At this time blood pressure and heart rate had returned almost to preblock levels. The return of lower limb sensation occurred slowly over the next hour or so. She made an uneventful recovery and was discharged home perfectly well about eight hours after the block. Blood sugar at discharge was $325 \mathrm{mg} / 100 \mathrm{ml}$.

At the follow-up visit to the clinic one week later, she remained symptom free.

\section{Comment}

It seems certain that this patient developed a total spinal block caudal from the level of C4 or C5. The absence of any cranial signs other than those related to the stellate ganglion on the left side and slight muscle weakness on the right clearly discounts accidental vascular injection, although this has been described as a complication of the paratracheal approach. ${ }^{11}$ Similarly, epidural injection can probably be discounted because of the rapidity of onset and the intensity of the block which resulted, particularly because bupivacaine is well known for its relatively slow spread in the epidural space. Direct dural puncture is a possibility; however, the superficial placement of the needle antero-medial to Chassaignac's tubercle on the transverse process of $\mathrm{C6}$, makes this highly unlikely. It seems probable that the small volume of local anaesthetic solution which was used in this case $(1 \mathrm{ml})$, entered the subarachnoid space through tissue planes which had been opened up by the larger volume $(5 \mathrm{ml})$ used on the previous day. The fact that the previous blocks using this larger dose had been uneventful when injected at exactly the same site but separated by three days, makes abnormal anatomy such as a herniated dural cuff most unlikely.

According to Bonica (1953), $1 \mathrm{ml}$ of isobaric solution injected into the subarachnoid space at C6 will result in anaesthesia of the segments C3 to T3, while the same volume injected into the epidural space at the same level will block only that segment. ${ }^{12}$ The extent of the resulting block in this case from C4-5 caudally, suggests that bilateral block of the lateral spinal tracts had occurred.

The rationale for employing the paratracheal approach for stellate ganglion block using injections at the level of $\mathrm{C} 6$ have recently been well documented by Carron \& Litwiller. ${ }^{2}$ Inserting the needle to a position 0.5 to $1 \mathrm{~cm}$ anterior to and 1 to $1.5 \mathrm{~cm}$ medial to Chassaignac's tubercle on the transverse process of $\mathrm{C} 6$, requires only about 3 to $5 \mathrm{ml}$ of solution to be injected to completely block the postganglionic sympathetic fibres supplying the arm. These workers suggest that the sympathetic chain at the level of $\mathrm{C} 6$ is in a different fascial plane than at $\mathrm{C} 7$ and lower. At the lower level, they argue, the prevertebral fascia crosses over the transverse processes of $\mathrm{C} 7$ to cover the anterior and medial scalene muscles. The scalene opening through which the roots of the brachial plexus run, has an envelope of pretracheal fascia which forms the beginnings of the axillary sheath. Thus, the volume of solution needed to completely block postganglionic fibres at the level of $\mathrm{C} 7$ is between 10 and $20 \mathrm{ml}$. On the other hand, at the level of $\mathrm{C} 6$ and above the cervical sympathetic chain lies medial and anterior to the prevertebral fascial covering of the longus colli and longus corvicis muscles as they cross over the 
transverse processes of the cervical vertebrae. Thus injection at this level can achieve complete sympathetic block with less than $5 \mathrm{ml}$ of solution. Certainly in our experience, this approach has much to recommend it for the reasons already cited. However it is clear that a potential hazard is introduced during serial injections when there is an inadequate interval between them. One considers in the light of this case that at least 48 hours should be allowed between successive blocks to permit tissue planes which may have spread during injection, to return to normal and so prevent leakage of local anaesthetic solution into the subarachnoid space.

This case is presented to stress that while complications from stellate ganglion block performed under ideal conditions by a physician experienced in the technique are rare, but that when such complications occur they can be life threatening. The following have been cited as the most frequent complications; ${ }^{8}$ (a) pleural puncture and pneumothorax, (b) intravascular injection, (c) epidural injection, (d) dural puncture and subarachnoid spread, (e) infection, (f) trauma to periosteum or the brachial plexus, (g) phrenic nerve block, (h) puncture of the oesophagus or trachea, and (i) hypersensitivity to the drug used. Severe arrhythmias do occur ${ }^{13}$ and indeed death has been reported. ${ }^{3}$

In conclusion, therefore, it is strongly recommended that stellate ganglion blocks should be done only by experienced physicians, in hospitals or clinics where adequate facilities are immediately available for cardiopulmonary support including tracheal intubation and ventilation. The paratracheal route is recommended for its technical ease and the low dose method for its greater safety. As indicated above, forty-eight hours should elapse between repeated blocks.

\section{SUMMARY}

A case is presented of repeated stellate ganglion block using the paratracheal approach at the level of $\mathrm{C} 6$ and using the low dose method. Subarachnoid spread of local anaesthetic resulted in total spinal block below the level of $\mathrm{C} 4$. The potential hazards of this technique of stellate ganglion block and methods of avoiding them are discussed, together with the possible mechanism in this case.

\section{RÉsuMÉ}

On présente une complication survenue au cours d'un traitement par blocages sériés du ganglion stellaire par la voie paratrachéale au niveau de C6: malgré les doses minimes utilisées avec cette méthode, la diffusion de l'anesthésique local s'est faite de telle manière qu'elle a provoqué une anesthésie rachidienne totale.

L'auteur discute des périls éventuels de cette technique de blocage du ganglion stellaire et des mesures à prendrepour les éviter; il cherche en outre à expliquer de façon plausible comment une telle complication a pu survenir dans ce cas.

\section{REFERENCES}

1. Orkin, L.R., PApper, E.M., \& Rovenstine, E.A. The complications of stellate and thoracic sympathetic nerve blocks. J. Thorac. Surg. 20: 911-22 (1950). 
2. Carnon, H. \& Litwiller, R. Stellate ganglion block. Anesth. Analg. 54: 567-570 (1975).

3. Balius Juli, R. \& Tonner Baduell, C. Complicationes mortales de las infiltraciones del ganglio estrellado Rev. Esp. Anest. 10: 192-200 (1963).

4. BLưvshtzin, L.M. Opasnosti i oslozhneniia novokainovoì blokady zvezdchatogo uzla. Klin. Khir. (Moskova) 3: 66-69 (1974).

5. Bonica, J.J. In "Management of Pain". Philadelphia: Lee and Febiger, p. 479 (1953).

6. Magora, F. An unusual complication after stellate ganglion block: a case report. Brit. J. Anaesth. 36: 379-380 (1964).

7. Moore, D.C. An unusual complication after stellate ganglion block. Brit. J. Anaesth. 36 : 601 (1964) (correspondence).

8. Paulsen, K. \& Reinhafidt, M. Nil nocere: Die Stellatumblocade und ihre Gefahren. München. Med. Wschr. 112: 817-823 (1970).

9. Price, J., Hvidt, V., \& KüHL, V. Stellatum-blockade Et tilfaelde med en sjaelden Komplikation. Ugeskr. Laeg. 129: 1750-1752 (1967).

10. KEIM, H.A. Cord paralysis following injection into traumatic cervical meningocele: complication of stellate ganglion block. New York J. Med. 70: 215-216 (1970).

11. Peng, A.T., Bufalo, J., \& Blancato, L.S. Rare complication during stellate ganglion block: a case report. Can. Anaesth. Soc. J. 17:640-642 (1970).

12. Bromage, P.R. Spread of analgesic solutions in the epidural space and their site of action: a statistical study. Brit. J. Anaesth. 34: 161-178 (1962).

13. Tochinai, H. Case of severe arrhythmia after stellate ganglion block. Jpn. J. Anesthesiol. 23: 548-552 (1974). 